\title{
CHARACTERISATION AND EFFECTS OF A XYLANASE ENZYME PREPARATION EXTRACTED FROM THERMOMYCES LANUGINOSUS CULTURES
}

\author{
J. KUTASI ${ }^{1}$, Á. BATA ${ }^{1}$, E. BRYDL ${ }^{2}$, P. RAFAI $^{2 *}$ and V. JURKOVICH ${ }^{2}$ \\ ${ }^{1}$ Dr Bata Research and Development LLC, H-2364 Ócsa, Pesti úti major, Hungary; \\ ${ }^{2}$ Department of Animal Hygiene, Faculty of Veterinary Medicine, Szent István \\ University, H-1078 Budapest, István u. 2, Hungary
}

(Received October 9, 2000; accepted February 8, 2001)

\begin{abstract}
This paper describes the production of an enzyme preparation from the fungus Thermomyces lanuginosus. Thermal resistance, $\mathrm{pH}$ stability and lignocellulolytic activity of the enzyme preparation high in xylanase were studied on a variety of grains and forages. The enzyme preparation preserved more than $70 \%$ of its original xylanase activity for 4 and $1 \mathrm{~h}$ at 60 and $70{ }^{\circ} \mathrm{C}$, respectively. The xylanase activity remained over $80 \%$ when the preparation was incubated for $30 \mathrm{~min}$ at $\mathrm{pH}$ 4.5. In vitro digestibility studies indicated that the enzyme digested $7.5,8.5$ and $8.0 \%$ of the dry matter (DM) of barley meal, wheat bran and oat meal samples, respectively. When applying 60 -min incubation, $7.5,7.3$ and $8.4 \%$ of $\mathrm{DM}$ of the oat straw, alfalfa hay and triticale straw was digested, respectively. When the time of digestion was increased to $360 \mathrm{~min}$, the sunflower hull showed $15.8 \%$ DM digestibility.
\end{abstract}

Key words: Thermomyces lanuginosus, xylanase, lignocellulolytic activity, thermal and $\mathrm{pH}$ stability

Polysaccharidase enzymes have been used since the early 1960s as feed additives in poultry and pig nutrition and much later (from the beginning of the 'nineties) also in cattle nutrition for the improvement of feed conversion efficiency and other production traits. Enzyme additives may be mixed to the feeds either directly, usually in $0.01-0.1 \%$ concentration, in order to aid the digestive processes in the (fore)stomach(s) and intestines, or they may be used for enzymatic pre-treatment of cereals and/or forages for enhancing degradation of nonstarch polysaccharides (NSP). These enzymes are produced industrially by fungal cultures (Van de Mierop and Ghesquiere, 1998). The main components of the enzyme mixtures are cellulase, xylanase, 1,4 -beta-endoglucanase, $\beta$-glucosidase, $\alpha$-amylase and $\alpha$-galactosidase. Of these enzymes, xylanase predominates in most of the preparations (Van de Mierop and Ghesquiere, 1998; Pack and Bedford, 1999).

\footnotetext{
"Corresponding author; E-mail: prafai@univet.hu; Fax: +36 (1) 478-4243
} 
Of the imperfect fungi, Aspergillus oryzae and A. niger, or Trichoderma viridis and Humicola insolens have been known to produce fibrolytic enzymes in submerged cultures (Gomes et al., 1993a; Bakalova et al., 1996). These fungi, however, may be cultured with equal success in solid-state media (e.g. mouldbran medium, Lisching et al., 1993; Alam et al., 1994). In this case the product may be dried presuming the enzymes produced are heat resistant. The xylanase enzyme produced by the best known thermal resistant fungus, $H$. insolens, may preserve most of its activity at $60^{\circ} \mathrm{C}(\mathrm{pH} \mathrm{6.0)}$, but at temperatures higher than this the activity fades away within minutes (Schülien et al., 1992). Xylanase enzymes produce maximum activity at $\mathrm{pH}$ 6.0-7.0. It follows that strong acidity prevalent in the stomach of monogastric animals ( $\mathrm{pH} 3.0-4.0)$ will destroy the overwhelming majority of the enzymatic activity (Lisching et al., 1993).

According to the investigations of Purkarthofer et al. (1993) and Bennet et al. (1998), the thermophilic filamentous, imperfect fungus, Th. lanuginosus, produces cellulase-free extracts high in xylanase $(2840 \mathrm{IU} / \mathrm{ml})$ and low in $\beta$ xylosidase $(1.8 \mathrm{IU} / \mathrm{ml}), \alpha$-glucosidase $(1.3 \mathrm{IU} / \mathrm{ml})$ and $\alpha$-arabinosidase $(1.0 \mathrm{IU} / \mathrm{ml})$ activity. The strain of Th. lanuginosus used in these experiments has been deposited at the National Collection of Agricultural and Industrial Microorganisms (Budapest, Hungary) under the identification code NCAIM 001288.

In our laboratory an attempt was made to produce an enzyme product from the fungus Th. lanuginosus high in xylanase activity using submerged cultures for further study. This paper reports the thermal and $\mathrm{pH}$ stability of the enzyme preparation and provides data on its lignocellulolytic activity on cereals and forages.

\section{Materials and methods}

\section{Production of the enzyme extract}

The fungus Th. lanuginosus was cultured by submerged fermentation on a corn cob mixture (CCM) at $50{ }^{\circ} \mathrm{C}$ according to methods described in the relevant literature (Schülien et al., 1992; Gomes et al., 1993b; Purkarthofer et al., 1993; Alam et al., 1994; Hoq et al., 1994; Hoq an Deckwer, 1995; Bennet et al., 1998). In our case one litre of the medium contained $30.0 \mathrm{~g} \mathrm{CCM}, 30 \mathrm{~g}$ yeast extract, $2.0 \mathrm{~g}$ ammonium sulphate, $3.0 \mathrm{~g}$ magnesium sulphate, $0.3 \mathrm{~g}$ calcium chloride, $0.5 \mathrm{~g}$ iron sulphate, $10 \mathrm{~g}$ di-hydrogen potassium sulphate, $5.0 \mathrm{~g}$ di-hydrogen potassium phosphate. Two hundred $\mathrm{ml}$ of this medium was measured into Erlenmeyer flasks of $500 \mathrm{ml}$ and then autoclaved at $121^{\circ} \mathrm{C}$ for $45 \mathrm{~min}$. The $\mathrm{pH}$ was adjusted to $\mathrm{pH}$ 6.0. Each culture medium was inoculated by a culture of Th. lanuginosus grown on a potato-dextrose agar-slant (Becton and Dickinson Laboratories) for 10 days at $50{ }^{\circ} \mathrm{C}$. Flasks containing the inoculated medium were shaken by an orbital shaker (Braun, Certomat S-II) at $150 \mathrm{rpm}$ and $50{ }^{\circ} \mathrm{C}$ for 6 days. When completed, the fungal broth culture was centrifuged for $10 \mathrm{~min}$ at 
$3000 \mathrm{rpm}$ and then 1 litre of the clear supernatant was added to $100 \mathrm{~g}$ yeastextract and spray-dried at $115{ }^{\circ} \mathrm{C}$ inlet and $60{ }^{\circ} \mathrm{C}$ outlet temperature by a Mini Spray Dryer (Büchi, B-191, Switzerland) according to the method described by Caesar and Mrsa (1996) and Bennet et al. (1998). The average xylanase activity of this air-dry enzyme preparation (EP) was $2660 \mathrm{IU} / \mathrm{g}$. [IU: one unit of xylanase activity was expressed as $\mu \mathrm{mol}$ of reducing (xylose equivalent) sugar released in one min.]

\section{Measurement of enzyme activity}

Since the relevant literature (Gomes et al., 1993b; Purkarthofer et al., 1993) has shown that the extract of the Th. lanuginosus cultures contains negligible quantities of polysaccharide enzymes other than xylanase, these experiments were restricted to measuring only the xylanase activity in the following way.

To prepare the enzyme solution (ES), $10 \mathrm{~g}$ EP was dissolved in $100 \mathrm{ml}$ of 0.05 mol phosphate buffer ( $\mathrm{pH}$ 6.5) and was homogenised by stirring for $30 \mathrm{~min}$ with a magnetic stirrer. After 5 min of sedimentation the supernatant was centrifuged for $10 \mathrm{~min}$ at $3000 \mathrm{rpm}$, then the xylanolytic activity was measured from the supernatant based on the method described by Bailey et al. (1992). Accordingly, $0.02 \mathrm{ml}$ of the diluted ES was added to $2.0 \mathrm{ml}$ oat-spelt xylane preparation of $1.0 \%$ (Sigma X 0550) and then incubated for $15 \mathrm{~min}$ at $\mathrm{pH} 6.5$ and $50{ }^{\circ} \mathrm{C}$. After centrifuging ( $3000 \mathrm{rpm}$ for $5 \mathrm{~min}$ ) the supernatant was used for assaying the quantity of reducing sugars by the method of Miller (1959). To $1 \mathrm{ml}$ of supernatant $3 \mathrm{ml}$ DNA (2-hidroxy-3.5-dinitrobenzoic acid) reagent was added and then boiled for $5 \mathrm{~min}$. After cooling to room temperature, the absorbance of the solution was measured spectrophotometrically (Specol 11, Carl Zeiss, Jena) at $540 \mathrm{~nm}$.

\section{Examination of the thermal and $p H$ stability of the EP}

$0.2 \mathrm{ml} \mathrm{ES}$ of $266 \mathrm{IU} / \mathrm{ml}$ activity dissolved in $1.8 \mathrm{ml}$ of $0.05 \mathrm{M}$ citratephosphate buffer was incubated either at constant temperature $\left(50{ }^{\circ} \mathrm{C}\right)$ with $\mathrm{pH} 4.5,5.5$ and 6.5 for $15 \mathrm{~min}$, or at invariant $\mathrm{pH}$ of 6.5 with temperatures of 60 , 70 and $80^{\circ} \mathrm{C}$ for $60-360 \mathrm{~min}$ (Gomes et al., 1993a; Lisching et al., 1993; Alam et al., 1994; Purkarthofer and Steiner, 1995). After incubation the residual activity was measured as indicated earlier.

\section{Lignocellulolytic activity of the EP on grain and forage substrates}

One gram of barley-, wheat-, oat- and rye-meal samples was soaked at $50{ }^{\circ} \mathrm{C}$ either in $100 \mathrm{ml}$ of ES that contained citrate-phosphate buffer (enzyme activity: $266 \mathrm{IU} / \mathrm{ml}$ ) or in dilutions of ES, where the enzyme activity was 133 and $66 \mathrm{IU} / \mathrm{ml}$, respectively. After 5 to $30 \mathrm{~min}$ incubation the quantities of reducing sugars were measured as described above (Miller, 1959). The lignocellulolytic 
activity was estimated as percent of xylose equivalent (M: $150.1 \mathrm{~g}$ ) reducing sugars expressed in \% of the dry matter (DM) of the sample. The results were compared to lignocellulolytic activity of a commercial enzyme preparation (CEP). In this case $10 \mathrm{~g}$ CEP was dissolved in $100 \mathrm{ml} 0.05 \mathrm{~mol}$ phosphate buffer to obtain $226 \mathrm{IU} / \mathrm{ml}$ enzyme activity. This solution was then used for soaking the grain samples in identical conditions described above.

Forage samples (triticale straw, oat straw, alfalfa hay and sunflower hulls) were treated in the same way with the difference that straw samples were incubated for 5 to $60 \mathrm{~min}$, and samples of the sunflower hulls were incubated for 5 to $360 \mathrm{~min}$.

\section{Results}

\section{Thermal stability}

The enzyme extract preserved more than $70 \%$ of its activity for $2 \mathrm{~h}$ when incubated at $60{ }^{\circ} \mathrm{C}$, and it decreased to below $50 \%$ only after $6 \mathrm{~h}$ of incubation (Fig. 1). The extract incubated at $70{ }^{\circ} \mathrm{C} \mathrm{kept} \mathrm{more} \mathrm{than} 70 \%$ of its activity for $1 \mathrm{~h}$ showing a sharp decline afterwards. Incubation at $80{ }^{\circ} \mathrm{C}$ proved deleterious to the enzyme activity, because the extract lost approx. 50 and $80 \%$ of its activity at the end of the 1st and 2nd hour of incubation, respectively, and there was no indication of enzymatic activity after the 4th hour of the experiment.

pH stability

At $\mathrm{pH} 4.5$ the extract retained the majority of its enzymatic capacity for 30 min, while the activity was halved by the 60th min of incubation (Fig. 2). At this $\mathrm{pH}$ the enzymatic activity was practically lost after $120 \mathrm{~min}$ of incubation. At $\mathrm{pH}$ 6.5, good activity was measured even after $3 \mathrm{~h}$ of incubation.

\section{Experiments with different grains}

More than $50 \%$ of the digestible dry matter content of the rye bran (Fig. 3), oat grits (Fig. 4), barley groats (Fig. 5) and wheat bran (Fig. 6) samples was dissolved within 5 min by the enzyme extracts studied. Maximum degradation was obtained by about the 15th min of the experiment and only in few cases went the digestion until min 30. In three of the four grains studied the enzyme extract produced more dissolved dry matter than the commercial enzyme preparation. In case of the barley (Fig. 5, 7.5 vs. 6.5\%) and rye (Fig. 3, 8.4 vs. $7.1 \%$ ) samples the difference proved modest, while the in case of oat grits the difference was considerable (Fig. 4, 8.0 vs. $6.0 \%$ ). The dry matter digestion of the commercial enzyme preparation on wheat bran samples (Fig. 6) was better than that of the experimental preparation. 


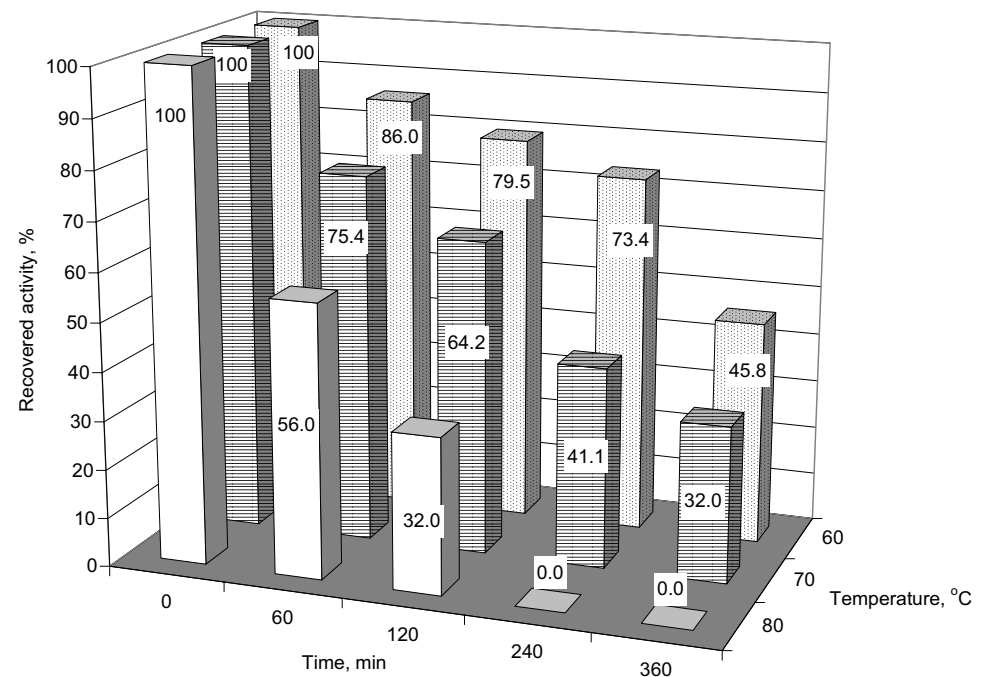

Fig. 1. Thermal resistance of the xylanase enzyme from Thermomyces lanuginosus at $\mathrm{pH} 6.5$

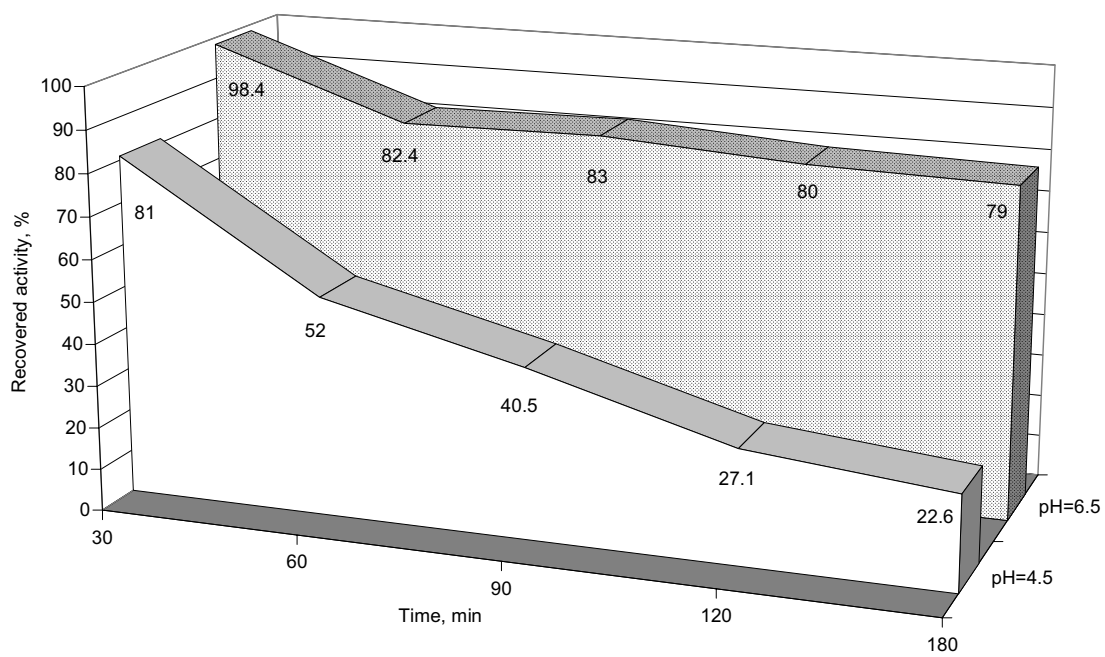

Fig. 2. Change of activity of xylanase enzyme from Thermomyces lanuginosus at different $\mathrm{pH}$ and at $50{ }^{\circ} \mathrm{C}$

\section{Experiments with forages and sunflower hulls}

The experimental enzyme extract started to degrade the organic material of oat straw, triticale straw, alfalfa hay and sunflower seed hulls after 5 min of digestion (Fig. 7). The concentration of the dissolved dry matter gradually increased until min 30 of incubation and in case of the sunflower, alfalfa, oat and 
triticale samples it reached 5.6, 5.4, 6.6 and 7.5\%, respectively. Beyond min 30 there was some further increment (Fig. 7).

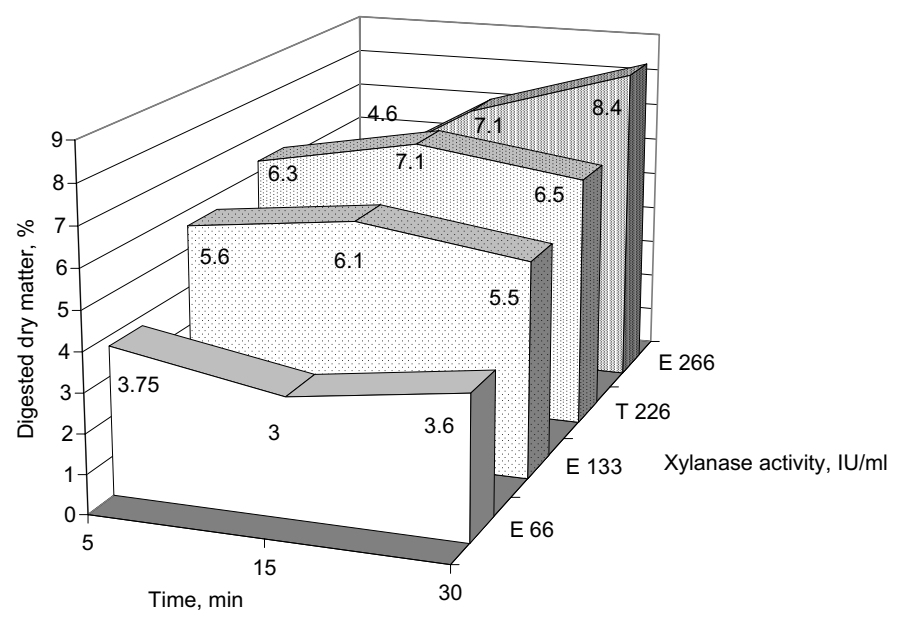

Fig. 3. Dry matter digestion of the xylanase produced in the present research at different activities (E) on rye bran substrate ( $\mathrm{pH}: 6.5$, temperature: $50^{\circ} \mathrm{C}$ ) in comparison with a commercial product $(\mathrm{T})$

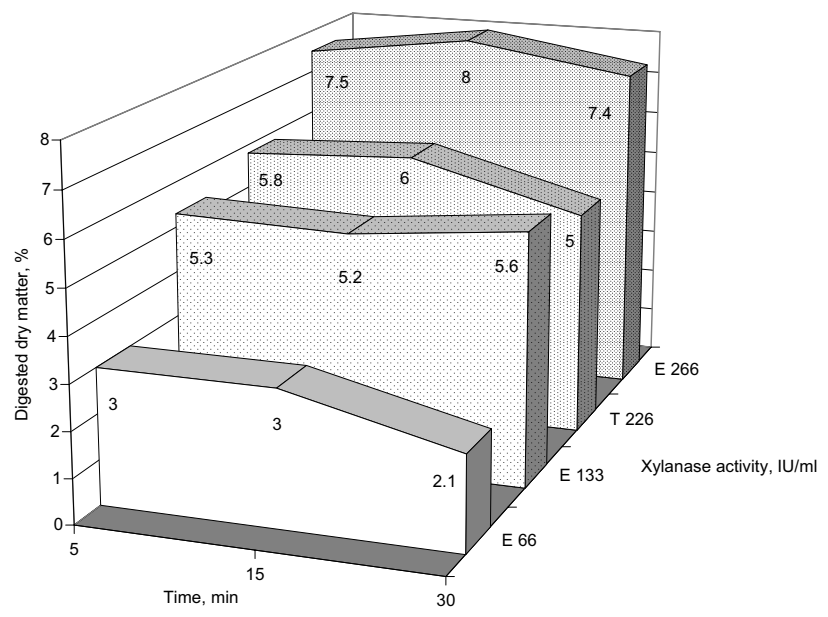

Fig. 4. Dry matter digestion of the xylanase produced in the present research at different activities (E) on oat meal substrate $\left(\mathrm{pH}: 6.5\right.$, temperature $50^{\circ} \mathrm{C}$ ) in comparison with a commercial product $(\mathrm{T})$ 


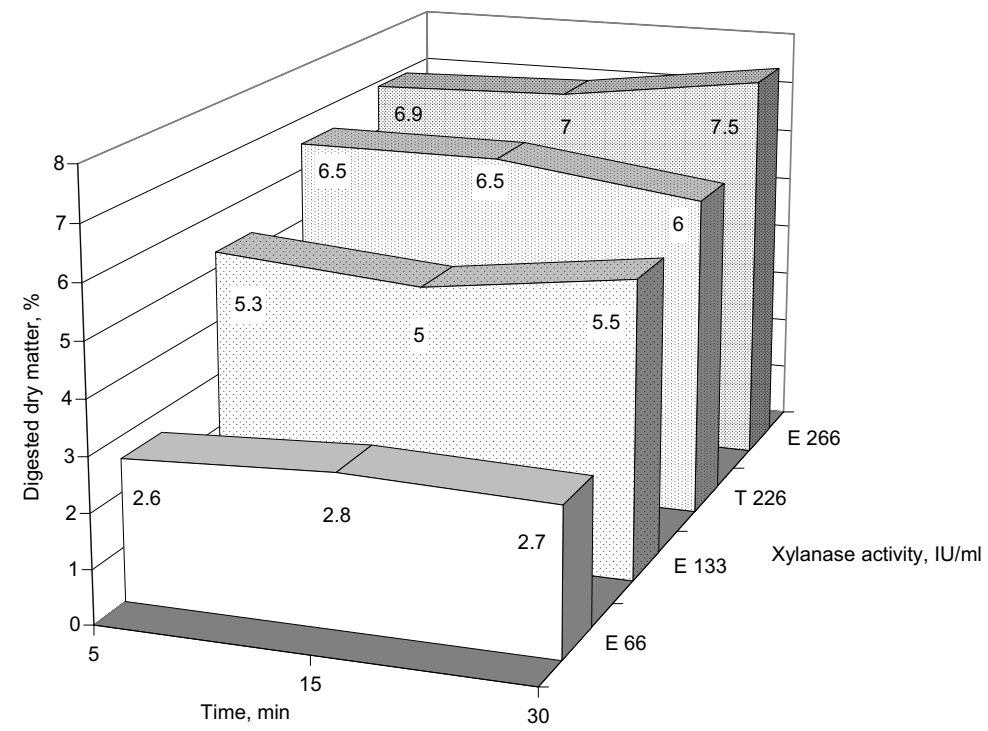

Fig. 5. Dry matter digestion of the xylanase produced in the present research at different activities (E) on barley meal substrate ( $\mathrm{pH}: 6.5$, temperature $50^{\circ} \mathrm{C}$ ) in comparison with a commercial product

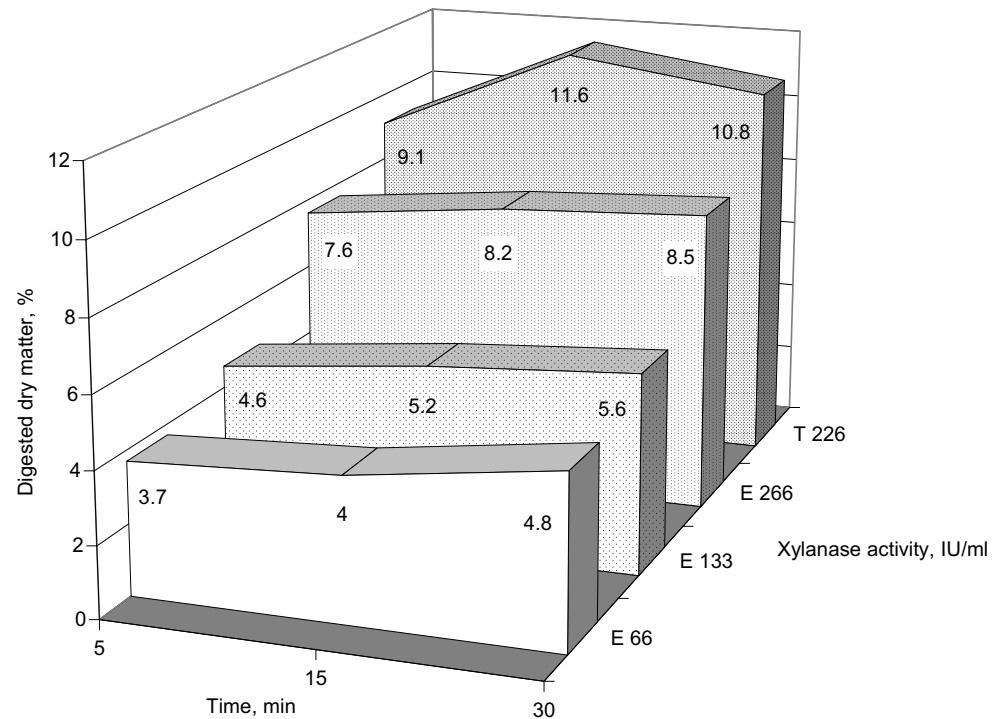

Fig. 6. Dry matter digestion of the xylanase produced in the present research at different activities (E) on wheat bran substrate $\left(\mathrm{pH}: 6.5\right.$, temperature $\left.50^{\circ} \mathrm{C}\right)$ in comparison with a commercial product 


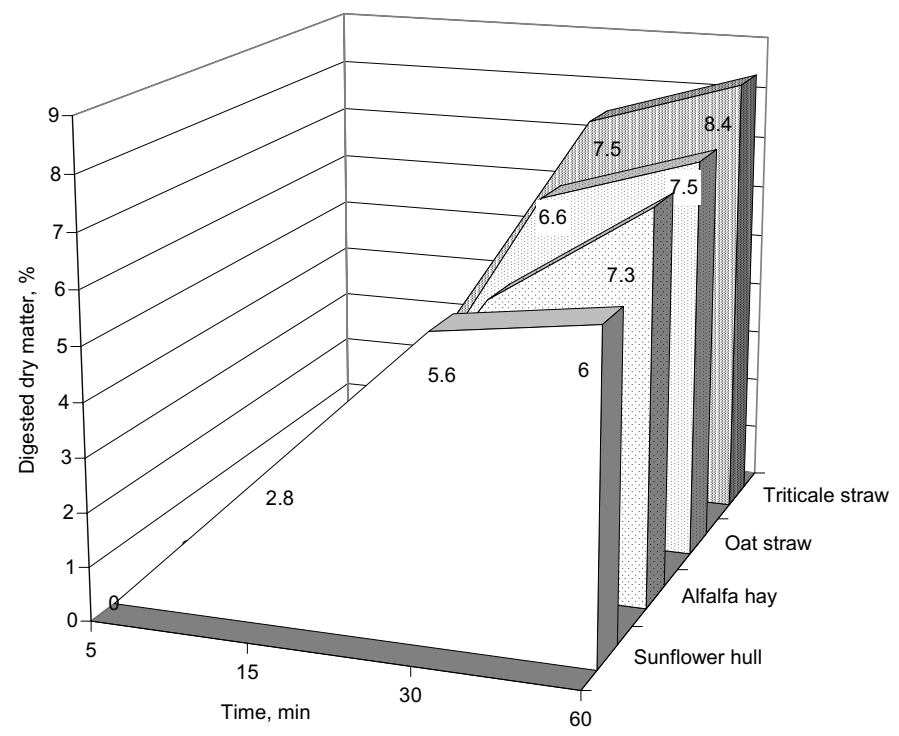

Fig. 7. Lignocellulolytic activity of xylanase from Thermomyces lanuginosus (activity: $266 \mathrm{IU} / \mathrm{ml}, \mathrm{pH}: 6.5$, temperature: $50{ }^{\circ} \mathrm{C}$ ) on forages

Sunflower seed hull samples were set for longer enzymatic incubation. As shown in Fig. 8, the concentration of the dissolved dry matter was 9.7, 14.3 and $15.8 \%$ at 90,210 and 360 min, respectively.

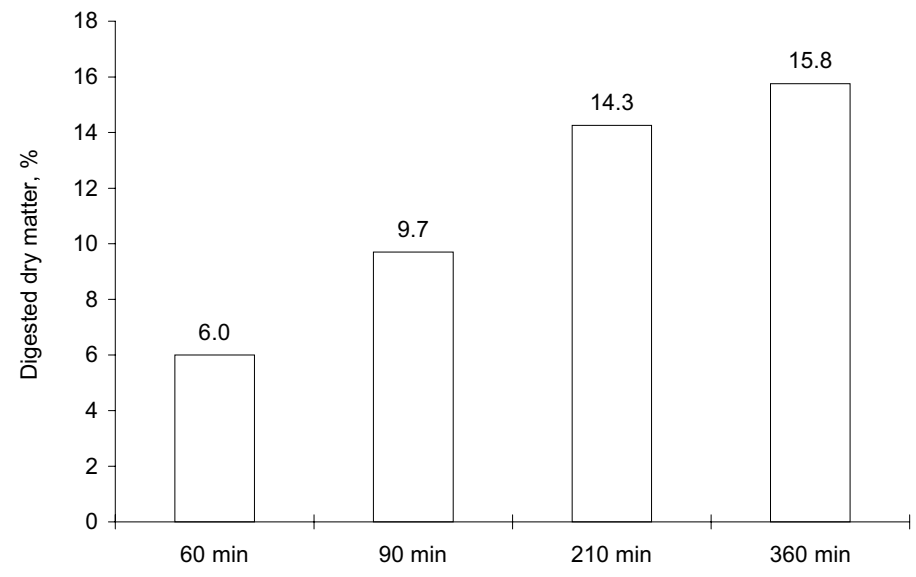

Fig. 8. Lignocellulolytic activity of xylanase from Thermomyces lanuginosus (activity: $266 \mathrm{IU} / \mathrm{ml}$, $\mathrm{pH}$ : 6.5, temperature: $50^{\circ} \mathrm{C}$ ) on sunflower hull substrate 


\section{Discussion and conclusion}

Thermal stability examinations indicated that the enzyme preparation has appropriate heat resistance. From this it follows that during the manufacturing of dry fermentation product, the enzyme preparation may be kept at $60{ }^{\circ} \mathrm{C}$ for as long as 2 to $3 \mathrm{~h}$ without considerable loss of enzyme activity. Owing to this the water content of the end product can be minimised. The enzyme preparation may be dried at 70 and $80{ }^{\circ} \mathrm{C}$, however, at these temperatures the length of drying should be reduced to 60 and $30 \mathrm{~min}$, respectively.

In acid environment the enzyme preparation preserves its enzymatic activity only for 30 to $60 \mathrm{~min}$. In monogastric animals the preparation may only be effective if it passes through the stomach with considerable speed. This may be the case with poultry (Bedford and Morgan, 1997; Pack and Bedford, 1999; Silversides, 1999).

Comparative study of grain samples revealed that the enzyme preparation works in a similar way as the commercial product studied in these experiments. Differences were found with wheat bran and oat grits. These differences might be attributed to the presence of auxiliary enzymes in our preparation and cellulase in the commercial product which was not measured in the present experiments. It has been reported (Gomes et al., 1993a; Gomes et al., 1993b; Purkarthofer et al., 1993; Alam et al., 1994; Hoq et al., 1994), that under appropriate culturing conditions, such as those applied in the present studies, the Th. lanuginosus fungal strains produce considerable quantities of xylanase with and without the presence of amylase and cellulase, respectively. The presence of amylase with no or negligible amount of cellulase in preparations rich in xylanase may either bring down or improve the digestive capacity of xylanase depending on the substrate quality (Gomes et al., 1993b; Purkarthofer et al., 1993; Alam et al., 1994). This may explain our findings that our enzyme extract had inferior and superior polysaccharidase activity on wheat bran and oat grit samples, respectively, in comparison with that of the commercial product.

Due to their high lignin content, forages and sunflower seed hulls contain considerably less available xylane than grains (Gomes et al., 1993b; Purkarthofer et al., 1993). This explains the relatively slow and less efficient lignocellulolytic activity. However, applying longer incubation, such as they were soaking in the aqueous enzyme preparation, polysaccharides might become available for the enzymes. This was observed in our experiment with the sunflower seed hulls, where the fungal enzyme digested three times more dry matter in $6 \mathrm{~h}$ than during a 1-h incubation.

The laboratory findings indicate that the enzyme extract of Th. lanuginosus fungal culture with dominant quantities of xylanase is especially suitable for enzyme supplementation of barley, rye and oat based feed mixtures for poultry and monogastric animals. 


\section{References}

Alam, M., Gomes, I., Mohuiddin, G. and Hoq, M. M. (1994): Production and characterization of thermostable xylanase by Thermomyces lanuginosus and Thermoascus auranticus grown on lignocelluloses. Enzyme Microb. Technol. 16, 298-302.

Bailey, M., Biely, P. and Poutanen, K. (1992): Inter laboratory testing of methods for assay xylanase activity. J. Biotechnol. 23, 257-270.

Bakalova, N., Petrova, S. and Kolev, D. (1996): Separation of enzymes from polyenzyme mixtures used in medicine and pharmacy. Pharmazie 51, 761-764.

Bedford, M. R. and Morgan, A. J. (1997): Method and composition for treatment and prophylaxis of coccidiosis. US Patent 5-624-678.

Bennet, N. I., Ryen, J., Biely, P. and Vrasanska, M. (1998): Biochemical and catalytic properties of an endoxylanase purified from the culture filtrate of Thermomyces lanuginosus ATCC 46882. Carbohydr. Res. 306, 445-455.

Caesar, T. and Mrsa, V. (1996): Purification and properties of the xylanase produced by Thermomyces lanuginosus. Enzyme Microb. Technol. 19, 289-296.

Gomes, J., Gomes, I., Kreiner, W., Esterbauer, H., Sinner, M. and Steiner, W. (1993a): Production of high level of cellulase-free and thermostable xylanase by a wild strain of Thermomyces lanuginosus using beechwood xylane. J. Biotechnol. 30, 283-297.

Gomes, J., Purkarthofer, H., Hayn, M., Kapplmüller, J., Sinner, M. and Steiner, W. (1993b): Production of a high level of cellulase-free xylanase by the thermophilic fungus Thermomyces lanuginosus in laboratory and pilot scales using lignocellulosic materials. Appl. Microbiol. Biotechnol. 39, 700-707.

Hoq, M. M. and Deckwer, W.-D. (1995): Cellulase-free xylanase by thermophilic fungi: a comparison of xylanase production by two Thermomyces lanuginosus strains. Appl. Microbiol. Biotechnol. 43, 604-609.

Hoq, M. M., Hempel, C. and Deckwer, W.-D. (1994): Cellulase-free xylanase by Thermomyces lanuginosus RT9: Effect of agitation, aeration, and medium components on production. J. Biotechnol. 37, 49-58.

Lisching, T., Purkarthofer, H. and Steiner, W. (1993): thermostability of endo-beta-xylanase from the thermophilic fungus Thermomyces lanuginosus. Biotech. Letter 15, 411-414.

Miller, G. L. (1959): Use of 2,4-dinitrosalicylic acid reagent for the determination of reducing sugar. Anal. Chem. 31, 426-428.

Pack, M. and Bedford, M. (1999): Best-cost approach optimises enzyme addition. Feed Tech. 2, 29-31.

Purkarthofer, H., Sinner, M. and Steiner, W. (1993): Cellulase-free xylanase from Thermomyces lanuginosus: optimization of production in submerged and solid-state culture. Enzyme Microb. Technol. 15, 677-682.

Purkarthofer, H. and Steiner, W. (1995): Induction of endo-beta-Xylanase in the fungus Thermomyces lanuginosus. Enzyme Microb. Technol. 17, 114-118.

Schülien, M., Heldt-Hansen, H. P. and Dalbqge, H. (1992): Xylanase corresponding recombinant DNA sequence, xylanase containing agent, and use of the agent. WO Patent 92, 17573.

Silversides, F. G. (1999): Soluble non-starch polysaccharides, enzymes, and gut viscosity - is there a connection? World Poultry 15, 17-18.

Van de Mierop, L. and Ghesquiere, H. (1998): Enzymes have a long life ahead. World Poultry 14, $16-18$ 